\title{
Dealing with the inevitable: Fire on Table Mountain
}

\section{BOOK TITLE:}

Burning Table Mountain: An environmental history of fire on the Cape Peninsula

\section{BOOK COVERS:}

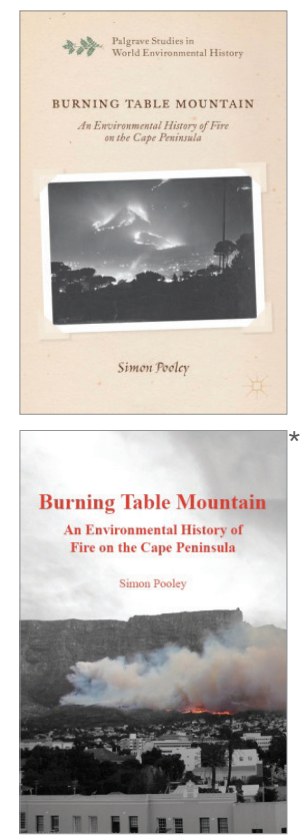

\section{AUTHOR:}

Simon Pooley

\section{ISBN:}

9781137415370 (hardcover); 9781137415387 (paperback); 9781775820017 (paperback)* $^{*}$

\section{PUBLISHER:}

Palgrave Macmillan, Basingstoke, GBP60 (hardcover)

\section{PUBLISHED:}

2014

*Available only in South Africa: UCT Press (ZAR295); 2015.

\section{REVIEW TITLE:}

Dealing with the inevitable: Fire on Table Mountain

\section{REVIEWER:}

Brian W. van Wilgen

EMAIL:

bvanwilgen@sun.ac.za

\section{AFFILIATION:}

Centre for Invasion Biology, Department of Botany and Zoology, Stellenbosch University, Stellenbosch, South Africa
Vegetation fires are the inevitable consequence of the co-occurrence of three vital ingredients - fuel to burn; hot, dry and windy weather; and a source of ignition. Table Mountain has all three, as early European colonists discovered very soon after their arrival at the Cape. Arriving as they did from the relatively fire-free regions of Europe, these colonists for centuries regarded fire solely as a destructive force. In ecological terms, however, fire is a natural feature of the Cape, regarded sometimes as a 'generalist herbivore' that indiscriminately consumes all plant species in its path. It is a process that shapes the structure and composition of vegetation communities in many of the earth's ecosystems. Managers of fire-prone landscapes therefore seek to influence fire regimes, both to protect lives and property from damaging wildfires, and to ensure the health of fire-adapted and fire-dependent species. This task has never been an easy one, as it requires trade-offs between the conflicting goals of biodiversity conservation and human safety, and in the case of Table Mountain is exacerbated by the divided opinions of a highly vocal and opinionated citizenry whose lives are closely affected by fires. It is thus extremely useful to have a historical account of how the understanding of fires and their management developed over time. Simon Pooley has produced an excellent review of this issue, using the Cape Peninsula as a case study.

As a background to the historical study, the book starts off with a review of the development of fire ecology in the fynbos. The science of fire ecology strives to understand and document the effects of fire on plants and animals, and the role that fire plays in maintaining healthy ecosystems. But managing fires requires more than just scientific understanding - it requires communication, consensus goal-setting, collaboration and coordination, all embedded in the humanities rather than in hard science. Fires (especially big fires) are also episodic and relatively infrequent. Big fire events are typically followed by highly visible postmortems, and usually culminate in promises to reorganise and improve fire management capacities. Equally typically, these promises are given lower priority as time passes, only to re-emerge again in dramatic form when there is another big fire. For example, the book quotes newspaper accounts of the 1982 fire as being 'the worst fire in almost four decades', when in fact equally large fires occurred only 10 years earlier. In Simon Pooley's words, these accounts 'reveal the fickleness of public memory, enhanced by an urge to dramatise current events'. Thus, although there has been a dramatic increase over the past 40 years in the understanding of the vital role that fires play in fynbos ecology, history shows how difficult it has been to use this knowledge in rational management.

Fire was seen by early colonists as a destructive force, and from the early 1900s was interpreted in terms of Clementsian succession as a process that retarded progress towards a (desirable) climax situation. Despite mounting evidence that fynbos plant species were adapted to fire, policies continued to promote fire exclusion. Calls by the influential Dr C.L. Wicht in 1945 to consider the use of fire in fynbos management went unheeded for more than two decades, against the background of a national concern about the detrimental effects of fire on soil erosion, and consequently on the ability of the nation to support itself. Bokkie the Grysbok, today the national symbol of wildfire awareness (and probably modelled on America's Smokey the Bear), was widely popularised in a fynbos fire-awareness booklet published in 1962, and helped to perpetuate the view of fires as agents of destruction. Today, the beneficial role of fire is widely recognised, but fire management remains controversial because of the need to simultaneously achieve the dual goals of protecting property and the public from wildfires while still allowing fire to play its necessary ecological role.

The management of fires on the Peninsula often fell to foresters, who established plantations of fire-sensitive trees in the fire-prone fynbos from the mid-1800s onwards. The history of tree-planting and forestry has also been characterised by opposing views regarding the value of trees. On the one hand, trees have over the years been seen as valuable sources of timber, as a means of protecting water resources, as providers of shade, and as an aesthetically pleasing cover for the mountain's bare slopes. On the other hand, concerns grew about the impact of foreign trees on the area's unique native flora, while evidence mounted that trees were detrimental rather than beneficial for water resources, and that they exacerbated wildfire effects. In addition, trees spread away from plantations - an invasion which was facilitated by wildfires. Concerns about these invasions were raised as early as 1888. In 1958, the Wild Flower Protection Committee of Kirstenbosch published a booklet entitled Green Cancers of South Africa, considerably raising awareness of the problem of invasion. The arguments about the value of foreign trees continue today, and opinions remain divided. However, the role of invasive trees in exacerbating the fire problem were brought to the fore following large fires in 2000 , resulting in the focus of management on the Peninsula shifting from fire to alien plant clearing.

Pooley also documents growing concerns about the ecological effects of increasingly frequent fires, brought about by growing numbers of people with access to the mountain. The ownership of cars by private citizens increased from the 1930s onwards, and the latter half of the 20th century saw a substantial expansion of the Peninsula's

\section{POSTAL ADDRESS:}

Department of Botany and Zoology, Stellenbosch University, Private Bag X1, Matieland 7602, South Africa

\section{HOW TO CITE:}

Van Wilgen BW. Dealing with the inevitable: Fire on Table Mountain. S Afr J Sci. 2015;111(1/2), Art. \#a0090, 2 pages. http://dx.doi.org/10.17159/sajs.2015/a0090

\section{(C) 2015. The Author(s).}

Published under a Creative Commons Attribution Licence. 
road network, with the net result that previously inaccessible areas experienced considerable increases in visitor numbers, and of course in accidental fires. Pooley argues that it is this access, rather than the overall increase in Cape Town's population, that is driving increases in the frequency of fires.

Overall, this is an excellent and well-written book that has been thoroughly researched. Unlike scientific accounts, which rely heavily on the peerreviewed literature, this account uses a myriad of additional sources, including newspaper articles, minutes of meetings, annual reports and interviews to produce an account of fire that reflects the evolving opinions and actions of scientists, policymakers, managers and the public at large. It is the first serious treatment of the interrelated development of fire science and fire policy in South Africa, and it takes the reader into the topsy-turvy world of divided opinion and competing institutions that ultimately have more influence on responses to environmental issues than does science. As such, it should be regarded as compulsory reading for students and practitioners of fynbos management. 